\title{
Index of Volume 80 (1998)
}

\section{Issue 1}

D. Schumann, M. Andrassy, H. Nitsche,

A. F. Novgorodov, R. Misiak, M. Schädel,

W. Brüchle, B. Schausten, J. V. Kratz,

H. Bruchertseifer

Sorption Behaviour of $\mathrm{W}, \mathrm{Hf}, \mathrm{Lu}, \mathrm{U}$, and Th on Ion Exchangers from $\mathrm{HCl} / \mathrm{H}_{2} \mathrm{O}_{2}$ Solutions. Model Experiments for Chemical Studies of Seaborgium (Sg) . . . . . . . . . . .

G. Pfrepper, R. Pfrepper, D. Krauss,

A. B. Yakushev, S. N. Timokhin, I. Zvara

Ion Exchange Equilibria and Stoichiometry of Complexes of Element 104 and Hafnium in Hydrofluoric Acid Solutions . . . . . . . . . . . .

K. S. Kung, N. Lu, I. R. Triay, K. M. Motyl,

W. J. Roushey

Chemical Extraction of Plutonium and Americium from Contaminated Rocky Flats Soil . . . . . .

O. S. Pokrovsky, M. G. Bronikowski,

R. C. Moore, G. R. Choppin

Interaction of Neptunyl(V) and Uranyl(VI) with EDTA in $\mathrm{NaCl}$ Media: Experimental Study and Pitzer Modeling . . . . . . . . . . . . 23

T. Muroyama, A. Shinohara, T. Saito,

A. Yokoyama, T. Miura, M. Furukawa Intensity Patterns of Pionic X Rays Emitted from Some Organic Compounds . . . . . . . . 31

D. L. Moir, A. W. Tarr, J. D. Chen,

D. P. Archambault, B. Payne, T. A. Shewchuk Determination of ${ }^{14} \mathrm{C},{ }^{3} \mathrm{H}$ and Gamma-Emitting Radionuclides in Irradiated $\mathrm{Zr}-2.5 \mathrm{Nb}$ Pressure Tubes .

S. P. Mishra, (Miss) Vijaya

Hot Atom Chemistry in Oxyanion Targets: Behaviour of Recoil ${ }^{56} \mathrm{Mn}$ in Lanthanum Permanganate .................. 43

S. P. Mishra, D. Tiwari, R. S. Dubey, M. Mishra Removal Behaviour of Rice (Oryza sativa L) Hulls for Submicro Concentrations of $\mathrm{Hg}^{2+}$ and $\mathrm{Cr}^{3+}$ from Aqueous Solutions: A Radiotracer Study
E.-H. Kim, J.-H. Yoo, C.-S. Choi

Removal of Palladium Precipitate from a Simulated High-level Radioactive Liquid Waste by Reduction by Ascorbic Acid . . . . . . . . . . . . . . . 53

\section{Issue 2}

Z. Szǘcs, W. Hamkens, S. Takács, F. Tárkányi,

H. H. Coenen, S. M. Qaim

Excitation Functions of ${ }^{14} \mathrm{~N}(\mathrm{~d}, \mathrm{t})^{13} \mathrm{~N}$ and ${ }^{14} \mathrm{~N}(\mathrm{~d}, \alpha \mathrm{n}){ }^{11} \mathrm{C}$ Reactions from Threshold to 12.3 MeV: Radionuclidic Purity of ${ }^{15} \mathrm{O}$ Produced via the ${ }^{14} \mathrm{~N}(\mathrm{~d}, \mathrm{n}){ }^{15} \mathrm{O}$ Reaction . . . . . . . . . . 59

\section{Pershina}

Solution Chemistry of Element 105. Part I: Hydrolysis of Group 5 Cations: $\mathrm{Nb}, \mathrm{Ta}, \mathrm{Ha}$ and $\mathrm{Pa}$. . .

\section{Pershina}

Solution Chemistry of Element 105. Part II: Hydrolysis and Complex Formation of $\mathrm{Nb}, \mathrm{Ta}, \mathrm{Ha}$ and $\mathrm{Pa}$ in $\mathrm{HCl}$ Solutions . . . . . . . . . . . . . . . 75

Y. Sasaki, G. R. Choppin

Extraction of $\mathrm{Np}(\mathrm{V})$ by $N, N^{\prime}$-dimethyl- $N, N^{\prime}$-dihexyl-3-oxapentanediamide ........ 85

M. Saeki, M. Nakada, T. Yamashita, T. Nakamoto, N. N. Krot

Synthesis and Properties of Some Neptunyl(V)

Phthalates . . . . . . . . . . . 89

M. Bouby, I. Billard, J. MacCordick, I. Rossini Complexation of Uranium VI with the Siderophore Pyoverdine .. . . . . . . . . . . . . 95

S. Ambe, T. Okada, F. Ambe

In situ Emission Mössbauer Studies on Carrier-Free ${ }^{57} \mathrm{Co}^{2+}$ and ${ }^{119} \mathrm{Sb}^{5+}$ Ions at Interfaces between Spinel-Type Oxides and Aqueous Solutions . . . . 101

D. Sandhya, M. S. Subramanian

Radiometric Determination of Trace Amounts of Cadmium by Liquid Scintillation Counting . . . 109 


\section{Issue 3}

\section{P. Reimer, S. M. Qaim}

Excitation Functions of Proton Induced Reactions on Highly Enriched ${ }^{58} \mathrm{Ni}$ with Special Relevance to the Production of ${ }^{55} \mathrm{Co}$ and ${ }^{57} \mathrm{Co}$. . . . . . . . 113

R. Günther, W. Paulus, J. V. Kratz, A. Seibert,

$P$. Thörle, S. Zauner, W. Brüchle, E. Jäger,

V. Pershina, M. Schädel, B. Schausten,

D. Schumann, B. Eichler, H. W. Gäggeler,

D. T. Jost, A. Türler

Chromatographic Study of Rutherfordium (Element 104) in the System $\mathrm{HCl} /$ Tributylphosphate (TBP)

C. Marquardt, J. I. Kim

Complexation of $\mathrm{Np}(\mathrm{V})$ with Humic Acid: Intercomparison of Results from Different Laboratories . . . . . . . . . . . . . . . . . 129

H. Rainer, J. Fachinger

Studies on the Long-Term Behaviour of HTR Fuel Elements in Highly Concentrated Repository-

Relevant Brines

Y. Ying, S. Yongwen, Y. Rudong

Synthesis and Characterization of the Periodato Complexes of Thorium(IV): $\mathrm{M}^{\mathrm{T} T h}\left(\mathrm{H}_{2} \mathrm{IO}_{6}\right)(\mathrm{OH})_{2}$

$.4 \mathrm{H}_{2} \mathrm{O}$. . . . . . . . . . . . . . 147

M. L. P. Reddy, R. Luxmi Varma,

T. R. Ramamohan

Enhanced Extraction and Separation of Trivalent Lanthanoids with 4,4,4-Trifluoro-1-phenyl-1,3-butanedione and Crown Ether . . . . . . . 151

P. Thakur, V. Chakravortty, K. C. Dash,

T. R. Ramamohan, M. L. P. Reddy

Synergistic Extraction of Uranium(VI) by Mixtures of $\beta$-Diketones and Structurally Related Crown Ethers . . . . . . . . . . . . . 155

Y. Yamada, T. Tominaga

Molecular Orbital Calculation of Mössbauer Parameters for Iron Carbonyl Compounds Isolated in Low Temperature Matrices
Issue 4

N. Takahashi, A. Yokoyama, H. Baba,

T. Yamaguchi, D. Yano, T. Saito, N. Nitani,

Y. Hamajima, T. Ohtsuki, K. Masumoto

Sudden Changes in the Characteristics of GDR Fission of ${ }^{238} \mathrm{U}$ around the Critical Energy for Nuclear Phase Transition . . . . . . . . . 17

S. Shibata, M. Imamura, K. Sakamoto, S. Okizaki, S. Shibutani, H. Matsumura, M. Furukawa, I. Fujiwara, H. Nagai, K. Kobayashi

Yield Measurements of ${ }^{7} \mathrm{Be}$ and ${ }^{10} \mathrm{Be}$ Produced by Photonuclear Reactions at Intermediate Energies: Intercomparison of Fragmentation Processes between Photon- and Proton-Induced Reactions . . . 18

N. I. Molla, S. Basunia, M. R. Miah,

S. M. Hossain, M. M. Rahman, S. Spellerberg,

S. M. Qaim

Radiochemical Study of ${ }^{45} \mathrm{Sc}(\mathrm{n}, \mathrm{p}){ }^{45} \mathrm{Ca}$ and ${ }^{89} \mathrm{Y}(\mathrm{n}, \mathrm{p})^{89} \mathrm{Sr}$ Reactions in the Neutron Energy Range of 13.9 to $14.7 \mathrm{MeV}$. . . . . . . . . . 189

C. Jérôme, M. Mertens, L. Martinot, R. Jérôme, D. Strivay, G. Weber

Potentiometric-Controlled Exchange of Actinide and Lanthanide Cations by Electrically Conducting Polymers Based Resin . . . . . . . . . . . . . 193

D. I. Kaplan, T. L. Gervais, K. M. Krupka Uranium(VI) Sorption to Sediments Under High $\mathrm{pH}$ and Ionic Strength Conditions _. . . . . . . . . 201

S. P. Mishra, D. Tiwary

Inorganic Particulates in Removal of Toxic Heavy Metal Ions: Efficient Removal of Cadmium Ions from Aqueous Solutions by Hydrous Manganese Oxide . . . . . . . . . . . . 213

T.-L. Ku, S. Luo, B. W. Leslie, D. E. Hammond Assessing in situ Radionuclide Migration from Natural Analog Studies: Response to McKinley and Alexander (1996) . . . . . . . . . . . 219

Author Index . . . . . . . . . . 225 


\section{Radiochimica Acta}

\section{Volume $80 \cdot$ Issue $4 \cdot 1998$}

N. Takahashi, A. Yokoyama, H. Baba,

T. Yamaguchi, D. Yano, T. Saito, N. Nitani,

Y. Hamajima, T. Ohtsuki, K. Masumoto

Sudden Changes in the Characteristics of GDR Fission of ${ }^{238} \mathrm{U}$ around the Critical Energy for Nuclear Phase Transition . . . . . . . . 171

S. Shibata, M. Imamura, K. Sakamoto, S. Okizaki, S. Shibutani, H. Matsumura, M. Furukawa,

I. Fujiwara, H. Nagai, K. Kobayashi

Yield Measurements of ${ }^{7} \mathrm{Be}$ and ${ }^{10} \mathrm{Be}$ Produced by Photonuclear Reactions at Intermediate Energies: Intercomparison of Fragmentation Processes between Photon- and Proton-Induced Reactions . . 181

N. I. Molla, S. Basunia, M. R. Miah,

S. M. Hossain, M. M. Rahman, S. Spellerberg,

S. M. Qaim

Radiochemical Study of ${ }^{45} \mathrm{Sc}(\mathrm{n}, \mathrm{p})^{45} \mathrm{Ca}$ and ${ }^{89} \mathrm{Y}(\mathrm{n}, \mathrm{p})^{89} \mathrm{Sr}$ Reactions in the Neutron Energy Range of 13.9 to $14.7 \mathrm{MeV}$. . . . . . . . 189

C. Jérôme, M. Mertens, L. Martinot, R. Jérôme, D. Strivay, G. Weber

Potentiometric-Controlled Exchange of Actinide and Lanthanide Cations by Electrically Conducting Polymers Based Resin . . . . . . . . 193

D. I. Kaplan, T. L. Gervais, K. M. Krupka

Uranium(VI) Sorption to Sediments Under High pH and Ionic Strength Conditions . . . . . . . 201

S. P. Mishra, D. Tiwary

Inorganic Particulates in Removal of Toxic Heavy Metal Ions: Efficient Removal of Cadmium Ions from Aqueous Solutions by Hydrous Manganese Oxide . . . . . . . . . . . . . 213

T.-L. Ku, S. Luo, B. W. Leslie, D. E. Hammond Assessing in situ Radionuclide Migration from Natural Analog Studies: Response to McKinley and Alexander (1996) . . . . . . . . 219

Author Index . . . . . . . . . . . . 225 
